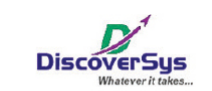

Published by DiscoverSys

\section{Internal and external factors of providing quality traditional health services in public health centres in Tabanan District, Bali, Indonesia}

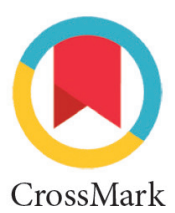

\author{
I Wayan Murdita, ${ }^{1,2 *}$ Dyah Pradnyaparamita Duarsa, ${ }^{3}$ I Nyoman Hariyasa Sanjaya ${ }^{4}$
}

\section{ABSTRACT}

Background and purpose: Traditional health services has been integrated into health services at the public health center (PHC), however, its implementation remains suboptimal. Situational analysis is required to identify implementation factors of traditional health services. This study aims to explore key strengths, weaknesses, opportunities and threats of providing quality traditional health services at PHCs in Tabanan District.

Methods: A qualitative study using an explorative case study design was conducted across PHCs in Tabanan District between January and February 2020. We utilized a SWOT analysis framework to facilitate our study. Data were collected through semi-structured in-depth interviews with 14 informants. They were purposively selected to allow rich data being collected. Six informants were considered as key informants and eight informants were considered as supporting informants. Data were analyzed using thematic approach.

Results: The strengths of PHCs in Tabanan District to provide quality traditional health services include commitment and competency of health providers, trust towards traditional medicine from health staff and community members, promotional activities, the tariff scheme and an established partnership with traditional healers. The weaknesses include limited numbers of staff, high workload of existing health providers and lack of supporting facilities and financial assistance. The opportunities include support from the community, the potency of traditional medicines, availability of government regulations, an established collaboration between traditional and conventional health services and potential customers brought by tourism industries of Bali Province. The threats include unlicensed traditional healers, lack of support from local governments and irresponsible promotional conducts.

Conclusion: Our study reveals key strengths, weaknesses, opportunities and threats of providing quality traditional health services at the PHC level in Tabanan District. Findings from our SWOT analysis can be used to develop strategies for improving implementation of traditional health services at the PHC level.

\footnotetext{
${ }^{1}$ Tabanan III Public Health Center, Tabanan, Bali ${ }^{2}$ Public Health Postgraduate Program, Faculty of Medicine, Udayana University ${ }^{3}$ Department of Public Health and Preventive Medicine, Faculty of Medicine, Udayana University ${ }^{4}$ Department of Obstetrics and Gynecology, Faculty of Medicine, Udayana University
}

*Correspondence to: I Wayan Murdita; Tabanan III Public Health Center, Tabanan, Bali; Public Health Postgraduate Program, Faculty of Medicine, Udayana University; yan_murdita@ yahoo.co.id

Keywords: SWOT analysis, traditional health services, public health centers.

Cite this Article: Murdita, I.W., Duarsa, D.P., Sanjaya, I.N.H. 2020. Internal and external factors of providing quality traditional health services in public health centres in Tabanan District, Bali, Indonesia. Public Health and Preventive Medicine Archive 8(2): 140-149. D0I: 10.15562/phpma.v8i2.309

\section{INTRODUCTION}

Universal Health Coverage (UHC) aims at ensuring all people have access to quality and affordable health services and providing financial risk protection when they get ill. ${ }^{1}$ Almost half of the world's population do not enjoy the highest attainable standard of health, and more than 100 million are at higher risk of becoming poor due to high healthcare costs they have to pay when they get sick. This situation have led to formulation of ambitious target to achieve UHC by 2030 endorsed by all member states of the United Nations - as a core element of sustainable development goals (SDGs). ${ }^{2}$

The World Health Organisation (WHO) states that safe, quality and effective traditional health services indirectly contribute to providing equal access to health services for all people, and consequently can contain healthcare costs. These premises have motivated the WHO to integrate traditional health services into the conventional or modern healthcare system. ${ }^{1}$ Traditional health services are defined as empirical health practices or approaches using medicines or other methods to treat, diagnose or prevent illness that have been practiced for generations and are adaptable to local norms. ${ }^{3}$

Following the WHO's recommendation, the Indonesian Government encourages the provision of traditional health services in hospitals and primary healthcare facilities. ${ }^{4}$ However, the utilization of traditional health services in Indonesia remains low. The Basic Health Survey (Riskesdas) in 2018 found only $31.4 \%$ households ever used traditional health services, a small increase from $30.4 \%$ in $2013 .{ }^{5}$

The Indonesian Health Bill No. 36/2009 states that traditional health services are one among 17 types of health services in Indonesia. ${ }^{6}$ The commitment of the Indonesian Government to improve the quality of traditional health services is 
further enhanced through various regulations. For example, the Government Regulation No. 103/2014 on Traditional Health Services; the Health Minister Regulation No. 61/2016 on Empirical Traditional Health Practices; the Health Minister Regulation No. 37/2017 on Integration of Traditional Health Practices; and the Health Minister Regulation No. 15/2018 on Complementary Traditional Health Practices. ${ }^{7}$

Alongside the national government, the Bali Government is also committed to improve the quality of traditional health services in Bali Province through enactment of the Bali Governor Regulation No. 104/2018 on the National Health Insurance Coverage (or locally called Peraturan Gubernur Bali Nomor 104/2018 tentang Jaminan Kesehatan Nasional Krama Bali Sejahtera). It outlines that traditional health services are included as additional benefits of the national health insurance program for people who reside in Bali. ${ }^{8}$ The Performance Accountability of Government Institution Report (LAKIP) of the Traditional Health Service, Directorate Ministry of Health of Indonesia between 2015 and 2018 stated that traditional health programs have been implemented by most public health centers (PHCs) in Indonesia, however, its implementation remains suboptimal. ${ }^{7}$ The Bali Province Health Office had reported similar situation for Bali Province in 2018 stating that the implementation of traditional health programs across PHCs in Bali remains limited and suboptimal. ${ }^{9}$

Studies regarding implementation of traditional health services at PHCs have been conducted in various locations in Indonesia such as Semarang, Makassar and Karo District North Sumatra. These studies suggest that quality implementation of traditional health services remains very limited. These studies largely focus on investigating barriers to quality implementation of traditional health services at PHCs. ${ }^{10-12}$ Studies or publications related to situational analysis to identify key strengths, weaknesses, opportunities and threats of providing quality traditional health services at PHCs are scarce. Indeed, developing key strategies to improve the quality of traditional health services at PHCs requires a robust situational analysis to identify internal and external drivers leading to quality improvement. Such analysis includes four components - strengths, weaknesses, opportunities and threats (SWOT), which all can influence the quality and effectiveness of traditional health services at PHCs. In addition, SWOT analysis has been widely used within the strategic management domain, including health service management. ${ }^{13}$

Tabanan is one among nine districts/cities of
Bali Province. It is characterized by its agricultural society enabling herbal remedies can be locally sourced. Furthermore, some people who reside in difficult to access subdistricts such as Pupuan, West Selemadeg and Baturiti face significant access barriers to healthcare facilities due to distance and geographical locations. The use of traditional health practices/services within these areas could assist community members in dealing with mild to moderate health issues. However, the Tabanan District Health Profile in 2018 reported that the implementation of traditional health services at PHCs remains suboptimal leading to limited utilization. ${ }^{14}$ This study was aimed at exploring key strengths, weaknesses, opportunities and threats of providing quality traditional health services at PHCs in Tabanan District. Findings of this study can be used to facilitate development of strategies to optimize implementation of traditional health services at PHCs.

\section{METHODS}

A qualitative study using an explorative case study design was conducted in Tabanan District from January to February 2020. Informants were purposively selected to provide rich information related to the topic of this study. A total of 14 informants were participated in the study comprising of six key informants and eight supporting informants. The head of PHCs with suboptimal (3 persons) and optimal (3 persons) traditional health services were recruited as key informants. Supporting informants were health staff in PHCs with suboptimal (2 persons) and optimal (2 persons) implementation of traditional health services, the Head of Referral and Traditional Health Division, Tabanan District Health Office (2 persons), clients of traditional health services (2 persons) and traditional healer (1 person).

Our study adopted SWOT Analysis framework to unpack facilitators or barriers to quality implementation of traditional health services. SWOT analysis is an instrument widely utilized in strategic management, including healthcare and health service management. SWOT analysis comprises of four key elements: internal component or within organization (strengths and weaknesses) and external component or outside organization (opportunities and threats). ${ }^{13}$

Data were collected through a semi-structured in-depth interview funneled by an interview guideline. Key interview questions included four major topics (strengths, weaknesses, opportunities and threats). We explained the study to the informants prior to data collection. We asked the informants to sign informed consent prior to the 
interview. Interviews were conducted at PHCs and houses of clients and traditional healer. On average, the interview lasted for about an hour. Interviews were conducted in Bahasa Indonesia and were auto recorded.

Data were analyzed using thematic approach as outlined by Miles and Huberman which includes developing coding trees, formulating categories and identifying core themes emerged from the data. ${ }^{15}$ We initiated data analysis by transcribing interview recordings and read the transcripts repeatedly to develop initial coding. Interconnections between codes were further analyzed to identify key categories followed by critically re-examined the transcripts to check consistency of meaning. These categories were further analyzed to reveal core themes, then it was narratively presented to provide coherent explanation for the questions being asked. We took into account feeling, opinion, perception and emotion of informants when interpreting the data being collected. Triangulation of sources of information were conducted to ensure the rigour of the study. Data were comprehensively presented using narrative approach following key themes emerged from the analysis.

This study has been approved by the Human Research Ethics Committee, Faculty of Medicine Udayana University/Sanglah General Hospital Denpasar (Protocol No. 72/UN14.2.2.VII.14/ LP/2020).

\section{RESULTS AND DISCUSSION}

\section{Socio-demographic characteristics of informants}

Table 1 depicts socio-demographic characteristics of key and supporting informants. All key informants for this study are public servants aged between 42-57 years with working duration of 13-25 years. The majority of key informants hold a medical qualification or master's degree in public health. Similarly, most of supporting informants were public servants aged between 32-54 years. We found that socio-demographic characteristics of informants from PHCs with optimal and suboptimal traditional health services are similar.

\section{Analysis of internal and external factors of quality traditional health services provision in PHCs in Tabanan District}

Findings of this study comprise of four components (strengths, weaknesses, opportunities and threats) which might influence the ability of PHC in providing quality traditional health services. The strengths and weaknesses components are internal factors, while the opportunities and threats components are external factors. These findings are summarized in Figure 1.

\section{Internal factors: strengths and weaknesses Key strengths}

For the purpose of this study, strengths are defined as internal conditions of PHCs that support quality implementation of traditional health services. A strong commitment and competency of health providers at PHCs are identified as key strengths of providing quality traditional health services. These strengths are expressed by informants from PHCs with optimal and suboptimal traditional health services. Our study reveals that a strong support from the head of PHC is more prominent in PHCs with optimal traditional health services. They are committed to quality improvement of the services and are willing to discuss problems associated with the services to identify solutions.

In contrast, the head of PHCs with suboptimal implementation of traditional health services are found to be 'situationally' supportive towards the traditional health program. If situations are not conducive, they choose to delay the program rather than exploring solutions for best implementing the program. These can be seen in the following quotes:

"I think a strong commitment from health staff is the key..." (The head of PHC, R1U01)

"I think competency is important, no doubt... Our staff have certificate and associated training, no issue with competency..." (The head of PHC, R2U06)

"Very critical here is because the head of PHC is very supportive, he will respond to our concerns if we report to him... [I think] that is the key... support and commitment from the head of $\mathrm{PHC}$ " (Health staff providing traditional health services, R1P01)

Furthermore, our study found that trust from health providers and community members towards traditional medicine is another key strength to provide quality traditional health services. These can be seen in the following scripts:

"Often... when relapse, I will go for acupressure because it works and make me feels better" (Client, RP06)

"Our society trusts the traditional health services, for example, many community members use the services, meaning that we need a standardized service for quality assurance" (Health staff providing traditional health services, $\mathrm{R} 2 \mathrm{P} 04$ )

PHCs have promoted traditional health services to community members using various outlets such as direct or face-to-face promotional activities and online media. This ongoing promotional activity by PHCs is also identified as key strength of providing quality traditional health services at 
PHCs. Promotion of traditional health services to the community is often conducted alongside other programs such as: at the integrated health post (or called Posyandu) or during community meetings. These can be seen in the following quote:

"We promote [traditional health services] through direct or face-to-face and indirectly through online media. Direct methods include for example in community meetings at community and subdistrict levels. We also promote [traditional health services] through online media or social media owned by the PHC" (The head of PHC, R1U02)

Another key strength identified from our study is the new tariff scheme for traditional health services at the PHC level. The new tariff scheme was introduced in early 2020 for all private patients while for insured patients are paid by the insurance.

"We hope that the new tariff scheme from the district government can trigger better quality of traditional health services at PHCs and can improve performance of PHCs in providing the services" (The head of PHC, R1U02)

Furthermore, existing partnerships between PHCs and traditional healers can improve the quality of services and ensure patient safety. PHCs engage with traditional healers to ensure appropriate referrals to $\mathrm{PHCs}$ or other health facilities are made by traditional healers if the cases are beyond their competency.

"We engage with traditional healers and show them evidence of the traditional medicines that can be used ... We also share and communicate with them, so we can introduce educational material such as safety, also we can initiate collaborative practices with them..." (The head of PHC, R1U02)

Our study found that key strengths to provide quality traditional health services identified from both PHCs with optimal and suboptimal services are very similar. The key difference is on the commitment of the head of PHC. A strong commitment from the head of PHC, such as by providing solutions for identified problems will determine quality implementation of traditional health services. Availability of health providers, trust from both health staff and community members and existing partnerships with traditional healers have been identified as key strengths for implementing traditional health services at the PHC level. ${ }^{13}$

Promotional activities conducted by PHCs to promote traditional health services are central in improving access to and utilization of the services by community members. It is hoped that these promotional activities will provide community members with consistent and correct information about traditional health services. Such information is crucial to improve their participation and utilization of traditional health services, particularly for mild health issues.

The new tariff scheme introduced by the local government since early 2020 is essential to motivate health staff to improve the quality of traditional health services. The new tariff scheme could address some financial barriers of PHCs in improving the quality of traditional health services. The new tariff scheme is also crucial in improving motivation of health staff/providers by providing financial incentives for their hard work; thus, will improve the overall quality of traditional health services.

These are several internal strengths from PHCs to provide quality traditional health services. It includes availability and competency of health providers, supportive regulation of local government, commitment of policy makers and the head of PHCs, commitment of implementing units, information and communication strategies and other internal factors that can facilitate quality implementation of traditional health services. ${ }^{16}$

\section{Key weaknesses}

For the purpose of this study, weaknesses are defined as internal conditions that can impede quality implementation or improvement of traditional health services at PHCs. Our study found that limited number of health staff to provide traditional health services is a common weakness across many PHCs. A limited number of health staff to implement traditional health services in Tabanan District requires serious interventions. Lack of health staff to implement the program reduces the ability of PHCs to engage with communities and to provide education about traditional health services to community members. The head of the traditional health program provides not only indoor health services but is also responsible for the community outreach and promotional activities. This situation has impeded ability of PHCs to engage with communities and can disrupt availability of indoor traditional health services to patients.

"We have limited staff, especially to provide education or outreach to communities, it will even more difficult later on when all villages under our jurisdiction establish traditional health service support, we definitely will have an increase workload to reach all groups..." (The head of PHC, R1U01)

Our study also found that a high workload among health providers at the $\mathrm{PHC}$ level is another key weakness to provide quality traditional health services. The head of traditional health program at PHCs across Tabanan District is also tasked with other programs leading to increase workload of 
Table 1. Socio-demographic characteristics of informants

\begin{tabular}{|c|c|c|c|c|c|c|}
\hline Code* & $\begin{array}{c}\text { Age } \\
\text { (year) }\end{array}$ & Sex & Occupation* & Level of Education & Position & $\begin{array}{c}\text { Working duration } \\
\text { (year) }\end{array}$ \\
\hline R1U01 & 42 & M & PNS & Master's in Public Health & Head of PHC & 14 \\
\hline R1U02 & 48 & M & PNS & Medical Doctor & Head of PHC & 14 \\
\hline R1U03 & 54 & $\mathrm{~F}$ & PNS & Medical Doctor & Head of PHC & 18 \\
\hline R2U04 & 49 & M & PNS & Dentist & Head of PHC & 13 \\
\hline R2U05 & 49 & M & PNS & Medical Doctor & Head of PHC & 16 \\
\hline R2U06 & 57 & M & PNS & Master's in Public Health & Head of PHC & 25 \\
\hline R1P01 & 54 & $\mathrm{~F}$ & PNS & Diploma in Sanitation & Health Promotion Officer & 30 \\
\hline $\mathrm{R} 1 \mathrm{P} 02$ & 48 & M & PNS & Bachelor of Nursing & Nurse & 29 \\
\hline $\mathrm{R} 2 \mathrm{P} 03$ & 51 & M & PNS & Bachelor of Nursing & Nurse & 30 \\
\hline $\mathrm{R} 2 \mathrm{P} 04$ & 53 & M & PNS & Diploma in Nursing & Nurse & 21 \\
\hline RP05 & 54 & M & PNS & Master's in Public Health & $\begin{array}{c}\text { Head of Traditional Health } \\
\text { Division }\end{array}$ & 29 \\
\hline RP06 & 32 & $\mathrm{~F}$ & Contract & Diploma in Midwifery & Midwife & 4 \\
\hline RP07 & 50 & $\mathrm{~F}$ & PNS & Diploma in Nursing & Nurse & 31 \\
\hline RP08 & 52 & $\mathrm{~F}$ & $\begin{array}{l}\text { Traditional } \\
\text { Healer }\end{array}$ & Senior High School & - & 20 \\
\hline
\end{tabular}

${ }^{*} \mathrm{R} 1=$ informants from PHCs with optimal traditional health services, $\mathrm{R} 2=$ informants from $\mathrm{PHCs}$ with suboptimal traditional health services, $\mathrm{RU}=\mathrm{key}$ informants, $\mathrm{RP}=$ supporting informants, $\mathrm{RP} 01-\mathrm{RP} 04=$ health staff providing traditional health services, RP05=official from the district health office, RP06-RP07=consumers, RP08=traditional healer, PNS=Pegawai Negeri Sipil (or public servant)

health staff.

"We are often responsible for multiple programs at the PHC, not only with the traditional health program but also other programs" (Official from the district health office, RP05)

Other key weakness identified from our study is lack of facilities and support system to implement traditional health services. For example, unavailability of a dedicated room to provide traditional health services, or unavailability of guidelines or standard operational procedures for different types of services.

"... limited facilities to support the program, for example no specific room to provide the services..." (The head of PHC, R2U05)

"No standard operational procedures outlining how each service should be delivered..." (The head of PHC, R1U03)

Limited funding or financial assistance to provide traditional health services is also another key weakness emerged from our study. It is expressed by PHCs with optimal and suboptimal traditional health services. It can be seen from the following quote:

"... [the financial assistance] is still limited... In 2019 we received enough budget, but now is reduced, the problem is we had designed more activities that require more funding..." (Health staff providing traditional health services, R1P01)

Key weaknesses emerged from this study are applicable to both PHCs with optimal and suboptimal traditional health services. These findings are consistent with a study conducted in the Halmahera PHC (Semarang) in 2016, which found that quality implementation of traditional health services is impeded by: lack of health workforce, limited budget, lack of incentives for health providers and lack of facilities. ${ }^{10}$ These key weaknesses can negatively influence the implementation of traditional health services at the PHC level. For example, limited number of health staff at PHCs along with high workload can lead to reduce performance. Furthermore, allocated budget from the district health office is also being reduced from the previous year which can negatively affect the coverage of the program, especially community 


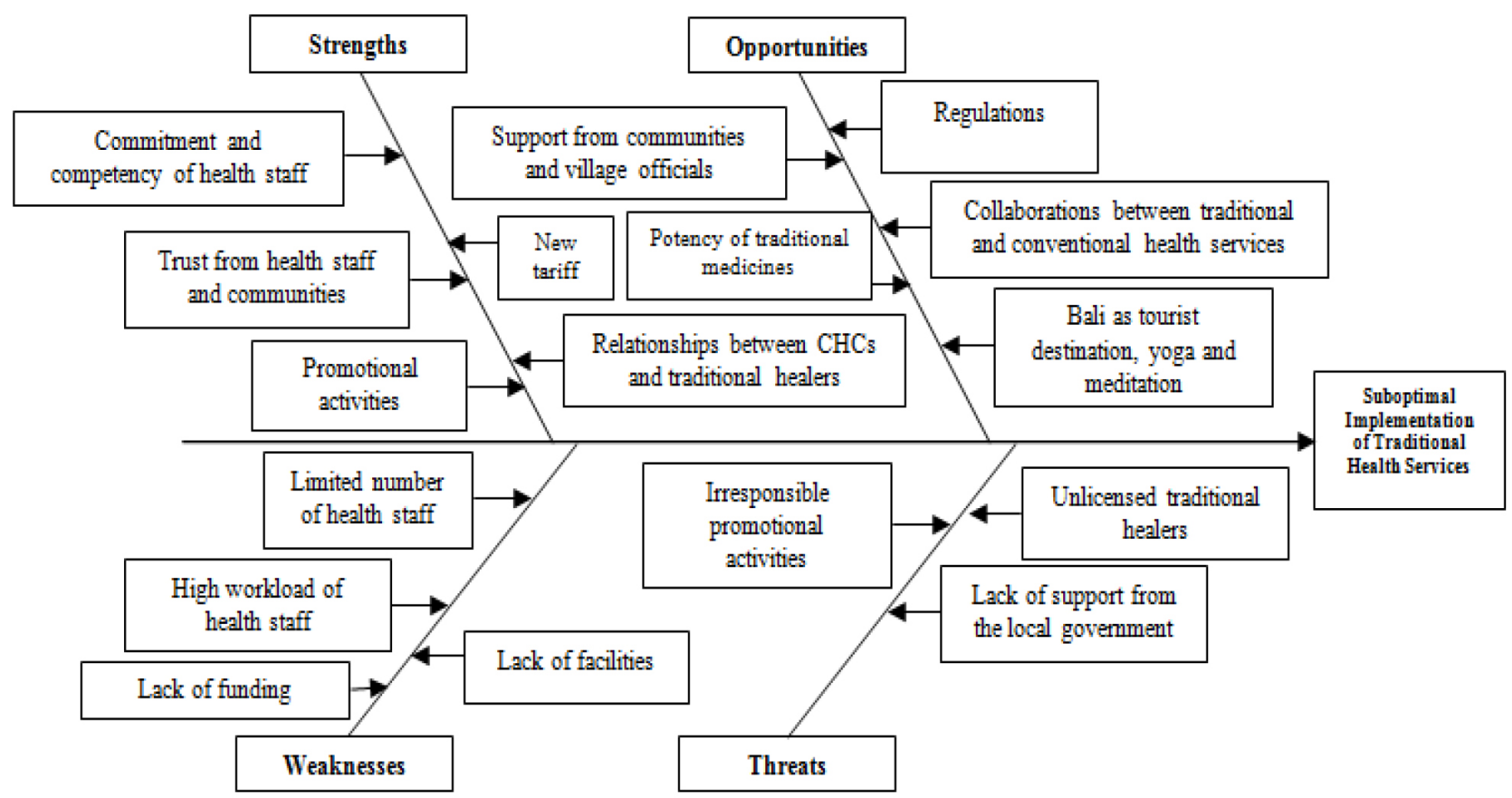

Figure 1. Key themes from the SWOT analysis

education and outreach activities.

Although health staff with appropriate skills and competencies are available at PHCs, implementation of traditional health services is impeded by the limited number of staff, high workload and lack of incentives. The head of traditional health program at the PHC is also responsible for other programs as well as providing indoor clinical care for patients. This situation is worse when supporting facilities, associated budget and incentives for health staff are limited.

\section{External factors: opportunities and threats Key opportunities}

Opportunities in this study are defined as external situations that facilitate PHCs to provide quality traditional health services. Firstly, the ongoing support from community members towards traditional health services. This includes an active participation of community members and village officials in many activities conducted by the traditional health program in their jurisdiction. Community members expressed their support and they hope that the program will be further developed. These can be seen from the following quote:

"Community members and village officials in these three villages are very supportive..." (The head of PHC, R1U03)

Ongoing support from community members is influenced by their beliefs and the empirical evidence of the use of traditional medicines for generations, and often is an integral part of their cultural practices, as can be seen in the following quote:

"... I think this is an opportunity, the local wisdoms and cultural practices of the community... Community members are enthusiastic about traditional medicines, including traditional herbal remedies because it is part of their local wisdoms..." (The head of PHC, R1U01)

All informants agreed that government regulations provide significant opportunities to further develop traditional health services at the $\mathrm{PHC}$ level, especially regulations from the national government. These regulations provide the basis for providing traditional health services at the PHC level and should be capitalized by local governments and PHCs to improve traditional health services.

"From our perspective as primary care provider, regulations from the national government and Bali Governor regarding the provision of traditional and complementary medicines in hospitals and PHCs are indeed opportunities that should be effectively utilized..." (The head of PHC, R2U05)

Furthermore, existing collaborations between conventional (western medicine) and traditional health services within the PHC level provide significant opportunities to further develop 
traditional health services. The conventional services at PHCs will continue to integrate traditional health services to maximize health benefits to patients and communities.

"The traditional health program collaborates with other heath programs at the PHC... This good collaboration will continue in our PHC; it will also improve the quality of traditional health services" (The head of PHC, R1U02)

As a famous tourist destination, mindfulness programs are well established in Bali Province, including meditation or yoga. These act as facilitators to further improvement of traditional health services at PHCs. Some PHCs in Tabanan district provide health services to various tourist objects/ destinations, which indeed can be optimized by PHCs to develop or expand their traditional health services.

"Bali Island is a famous tourist destination and spiritual journey... this provides an opportunity to further development of traditional health services in Bali" (The head of PHC, R2U05)

Key opportunities identified from our study are applicable to PHCs with optimal and suboptimal traditional health services. Opportunities are circumstances that can be leveraged to address internal weaknesses of an organization. When a company or an organization have identified their key opportunities, they can use these information to design intervention strategies to achieve their objectives. ${ }^{16,17}$

A study about utilization of acupressure and herbal remedies in Tabanan III PHC in 2019 have identified various opportunities as identified by our study, in particular the ongoing support and trust from community members about traditional health services. They also found that the level of knowledge and attitudes from consumers were generally good. This situation signals a great demand from the community for acupressure service and herbal remedies as alternative or complementary health services for the community. ${ }^{18}$ Similarly, a study examining acceptability of traditional health services, especially acupressure, in Tabanan III PHC found positive attitudes and perceptions regarding traditional health services from all informants. They are open and accept these services and wish that the services will be available to all patients. ${ }^{19}$

The WHO recommends the development of eastern medicine globally. A study in Bulgaria identified that this recommendation has facilitated further development of traditional health servicesin their study location. Furthermore, they also found other significant opportunities to provide traditional health services which include: ongoing support from the European Parliament to provide eastern medicine, expansion of complementary medicine practices in the USA and UK, recognition of acupressure and moxibustion from UNESCO, integration of eastern medicine into the national health bill, and the openness of Bulgarian's society toward eastern medicine. ${ }^{20}$ Similarly in Indonesia, traditional and complementary medicine is one among 17 types of health services recommended by the National Health Bill No. 36/2009. ${ }^{6}$ Additionally, the Indonesian Government also released several regulations to support implementation of traditional and complementary medicine in hospitals and PHC. For example, the Government Regulation No. 103/2014 about traditional health services, the Health Minister Regulation No. 61/2016 about empirical traditional health services, the Health Minister Regulation No. 37/2017 about integrating traditional health servicesinto healthcare system, and the Health Minister Regulation No. 15/2018 about complementary traditional health services. ${ }^{7}$

Indonesia has abundant herbs and medicinal plants that can be used as herbal remedies to support implementation of traditional medicine practices in primary care settings. Indonesian societies have used both physical and non-physical traditional healing practices for generations. There are many tourist destinations across Indonesia where traditional health services can be integrated into tourism industries. A study conducted in Turkey in 2014 examining health development strategies has identified that the expansion of tourism industries is one of key opportunities that should be leveraged to further develop health sector in their study location. ${ }^{21}$

\section{Key threats}

Threats in this study are defined as external factors that can impede implementation of traditional health services at PHCs. We found that the majority of traditional healers in Tabanan District are not certified or unlicensed practitioners (locally called Surat Terdaftar Penyehat Tradisional). This considers as a significant threat by informants.

"Until now very few of traditional healers are licensed, only two traditional healers apply for the license" (The head of PHC, R1U03)

Our study found the lack of support from the district government as another significant threat that will impede implementation of traditional health services at the PHC level. For example, unclear regulations and limited availability of technical guidelines from the district health office about implementation of traditional health services at the PHC level.

"The national government is committed... it releases various regulations to support 
implementation of traditional health services at the PHC level, however, these regulations are not well translated into local level... Until now there are limited technical guidelines and lack of support from the local government including limited allocation of resources from the local government... Even though it gains priority at the national level, it is not quite the case yet at the local level..." (The head of PHC, R1U02)

We also identified irresponsible promotional activities about traditional health services as another external threat. Informants in our study said that there are many promotional materials being distributed to households containing traditional medicine products with unknown safety. Such situation could lead to negative perceptions towards traditional health services and reduce utilization of the services by community members.

"Sometimes there are various media providing incorrect information about traditional health services or traditional medicine products..." (Health staff providing traditional health services, R1P02)

The key external threats identified in our study are applicable to PHCs with optimal and suboptimal traditional health services. Implementation of health programs will always face external factors that can impede or facilitate program effectiveness. External threats can reduce ability of an organization to implement or deliver health program optimally. ${ }^{13,16}$

The Government Regulation No. 103/2014 about traditional health services states that traditional healers provide empirical traditional health services. ${ }^{22}$ However, limited number of licensed traditional healers in Tabanan District can reduce quality implementation of traditional health services. Our finding is consistent with a study exploring legality of traditional health services in Indonesia. This study suggests that legality of empirical traditional health services is lower than integrated and complementary traditional health services. It suggests that empirical traditional health services have limited legal protection. Empirical traditional health services only require a traditional health registration letter (or locally called Surat Terdaftar Penyehat Tradisional/STPT), while integrated and complementary traditional health services require a registration certificate of traditional health practitioner (or locally called Surat Tanda Registrasi Tenaga Kesehatan Tradisional/ STRTKT) and a license to practice for traditional health practitioner (or locally called Surat Ijin Praktik Tenaga Kesehatan Tradisional/SIPTKT). The above situation indicates that licensing for traditional healers is still problematic. ${ }^{23}$

In terms of the lack of local regulations and technical guidelines, our finding is consistent with a study exploring implementation of standardized traditional remedies conducted in BKTM Makassar, Karanganyar 'A' PHC and Research Centre and Development for Traditional Medicine and Medicinal Plants (or locally called Balai Besar Penelitian dan Pengembangan Tanaman Obat dan Obat Tradisional/B2P2TOOT). This study found that no regulation to protect health staff as traditional health service providers. ${ }^{11}$ Lack of support from the local government has also identified as a significant threat in an evaluation study of a clean water and sanitation program in Tegal and Brebes Districts. ${ }^{24}$

Irresponsible promotional activities about traditional health services both directly using faceto-face and indirectly through online media are part of unhealthy business competition. This finding is consistent with a SWOT analysis of expanding markets for apple-based snacks in Malang Raya in 2015. This study found the existence of unhealthy competition across many actors. The study suggests that product information must be correctly and consistently provided to consumers, and producers are expected to implement responsible promotional activities by providing correct product information to consumers. ${ }^{25}$

\section{Implications for practice}

Our study reveals key strengths, weaknesses, opportunities and threats of providing quality traditional health services at the PHC level in Tabanan District. Findings from our SWOT analysis can be used by PHCs, the Tabanan District Health Office and related stakeholders to develop strategies to improve implementation of traditional health services across PHCs in Tabanan District. Key strengths identified through the SWOT analysis need to be leveraged to capitalize identified opportunities, to address existing weaknesses and to anticipate potential threats. Further strategic management study is required to analyse and formulate initiatives to improve implementation of traditional health services at the PHC level.

\section{Limitations}

Our study is limited to one district of Bali Province. Findings from this study might not generalizable to other settings in Bali Province or Indonesia.

\section{CONCLUSION}

Our study reveals key strengths of PHCs in Tabanan District to provide traditional health services include a strong commitment and competency of health providers, trust towards traditional medicine, promotional activities, the new tariff scheme and an established partnership with traditional healers. 
However, this study documents several internal weaknesses that require further attention: limited numbers of staff, high workload of existing health providers and lack of supporting facilities and financial assistance. Our study identifies various opportunities that can be leveraged: support from the community, the potency of traditional medicines, availability of government regulations regarding traditional health services, an established collaboration with conventional or modern health services, and potential customers brought by tourism industries of Bali Province.

External threats that can hamper the implementation of traditional health services include unlicensed traditional healers, lack of support from local governments, and irresponsible promotional conducts. Our study suggests that PHCs and related stakeholders need to develop further strategies to capitalize key strengths and opportunities, as well as to anticipate key weaknesses and threats identified through SWOT analysis of our study.

\section{Acknowledgements}

The authors thank the head of Health Office of Tabanan District and the head of PHCs in Tabanan District for their support in this study. The authors also thank informants who participated in this study for their contribution.

\section{Author Contribution}

WM designed and conceived the study, gathered and analyzed the data, prepared draft and edited the manuscript. DPD and NHS provided feedback and edited the manuscript.

\section{Conflict of Interest}

All authors declare no conflict of interest.

\section{Funding}

The study was self funded by the authors.

\section{REFERENCES}

1. World Health Organization. WHO Traditional Medicine Strategy. Geneva: World Health Organization; 2013.

2. World Health Organization. Universal health coverage (UHC). Geneva: World Health Organization; 2019.

3. Ministry of Health of Indonesia. Kurikulum dan Modul Training of Trainer Akupresur untuk pelayanan di Puskesmas [Curriculum and Module for Acupressure Training of Trainer for services in Public Health Centre]. Jakarta: Ministry of Health of Indonesia; 2012.

4. Ministry of Health of Indonesia. Kurikulum dan Modul Training of Trainer Asuhan Mandiri Pemanfaatan Toga dan Akupresur [Curriculum and Module for Training of Trainer Self-Care Utilization of Toga and Acupressure]. Jakarta: Ministry of Health of Indonesia; 2018.

5. Ministry of Health of Indonesia. Riset Kesehatan Dasar (Riskesdas) [Indonesia Basic Health Research]. Jakarta:
Ministry of Health of Indonesia; 2018.

6. Undang-Undang Kesehatan Nomor 36 Tahun 2009 [The Indonesian Health Bill No. 36/2009]. Jakarta; 2009.

7. Ministry of Health of Indonesia. Laporan Akuntabilitas Kinerja Instansi Pemerintah (LAKIP) Tahun 2018 [The Performance Accountability of Government Institution Report 2018]. Jakarta: Ministry of Health of Indonesia; 2018.

8. Bali Provincial Government. Peraturan Gubernur nomor 104 tahun 2018 tentang Jaminan Kesehatan Nasional Krama Bali Sejahtera [The Bali Governor Regulation No. 104/2018 on the National Health Insurance Coverage]. Denpasar; 2018.

9. Bali Provincial Health Office. Evaluasi Yankestrad Integrasi di Puskesmas [Evaluation of Tradisional Health Services Integration in Public Health Centre]. Denpasar: Bali Provincial Health Office; 2019.

10. Rahmawati A, Jati SP, Sriatmi A. Analisis Implementasi Pengintegrasian Pelayanan Kesehatan Tradisional di Puskesmas Halmahera Kota Semarang [Analysis of Implementation of Traditional Health Services Integration at Halmahera Health Center in Semarang City]. Semarang: Universitas Diponogoro; 2016.

11. Kristiana L, Maryani H, Lestari W. Gambaran Pelaksanaan Pelayanan Kesehatan Tradisional Ramuan Menggunakan Jamu Tersaintifikasi (Studi Kasus di BKTM Makassar dan Community Health Centre A Karanganyar) [Overview of The Implementation of Traditional Herbal Health Services Using Modified Herbs (Case Study at BKTM Makassar and A Public Health Center Karanganyar)]. Media Penelitian dan Pengembangan Kesehatan. 2017;27(3):185-196.

12. Ismedsyah, Sembiring SA. Evaluasi Implementasi Regulasi Pelayanan Kesehatan Tradisional Empiris oleh Penyehat Tradisional di Kabupaten Karo [Evaluation of The Implementation of Empirical Traditional Health Care Regulations by Traditional Healers in Karo District]. 2019. [cited 2019 October 6]. Available from: https://prosiding. seminar-id.com/index.php/sainteks/article/view/152.

13. Wijayati H. Panduan Analisis SWOT Untuk Kesuksesan Bisnis [SWOT Analysis Guide to Business Success]. Yogyakarta: Quadrant; 2019.

14. Tabanan District Health Office. Pelaksanaan Pelayanan Kesehatan Tradisional di Puskesmas [Implementation of Traditional Health Services in Public Health Centre]. Tabanan: Tabanan District Health Office; 2019.

15. Rijali A. Analisis Data Kualitatif [Qualitative Data Analysis]. Jurnal UIN Antasari. 2018;17(33):81-95.

16. Rangkuti F. Analisis SWOT: Teknik Membedah Kasus Bisnis [SWOT Analysis: Business Case Dissecting Techniques]. Jakarta: PT Gramedia Pustaka Utama; 2018.

17. Rangkuti F. Personal SWOT Analysis: Peluang di Balik Setiap Kesulitan [Personal SWOT Analysis: The Opportunities behind Every Difficulty]. Jakarta: PT Gramedia Pustaka Utama; 2018.

18. Nuartini N, Sagitarini N. Gambaran Pengetahuan dan Sikap Pasien tentang Asuhan Mandiri Ramuan dan Akupresur di Poli Kebidanan Puskesmas Tabanan III [Overview of Patient Knowledge and Attitude towards Herb Self-Care and Acupressure in Midwifery Polyclinic at Tabanan III Public Health Centre]. 2019. [cited 2019 September 18]. Available from: http://ojs.itekes-bali.ac.id/index.php/jrkn/ article/view/140.

19. Susanti NLPD, Nuartini N, Miyuliati N. Penerimaan Ibu Nifas terhadap Terapi Akupresur untuk Meningkatkan Produksi ASI Ditinjau dari Sudut Penerima dan Pemberi Layanan di Puskesmas Tabanan III [Postpartum Mothers' Acceptance of Acupressure Therapies to Increase Breast Milk Production is Reviewed from the Point of Recipients 
and Service Providers at Tabanan III Public Health Centre]. 2019. [cited 2019 September 3]. Available from: http://ojs. itekes-bali.ac.id/index.php/jrkn/article/view/141.

20. Vankova D. SWOT analysis of Eastern Medicine developments in Bulgaria. 2018. [cited 2019 November 26]. Available from: http://journals.mu-varna.bg/index. $\mathrm{php} / \mathrm{sssp} /$ article/view/5580/4960.

21. Aslan I, Çınar O, Özen Ü. Developing Strategies for the Future of Healthcare in Turkey by Benchmarking and SWOT Analysis. 2014. [cited 2019 November 26]. Available from: https://www.researchgate.net/ publication/269332567_Developing_ Strategies_for_the_ Future_of_Healthcare_in_Turkey_by_Benchmarking and SWOT Analysis.

22. Peraturan Pemerintah Republik Indonesia Nomor 103 Tahun 2014 [Republic of Indonesia Government Regulation Number 103/2014]. Jakarta; 2014.

23. Heriani I, Munajah. Aspek Legalitas Terhadap Pelayanan Kesehatan Tradisional di Indonesia [Legal aspects of
Traditional Health Services in Indonesia]. Jurnal Hukum Universitas Islam Kalimantan. 2019;53(9):1689-1699.

24. Kholiq A. Evaluasi Keberhasilan Program Air Minum dan Sanitasi (PAMSIMAS) di Kabupaten Tegal dan Kabupaten Brebes [Evaluation of The Success of Drinking Water and Sanitation Program in Tegal and Brebes Districts]. 2015. [cited 2020 April 3]. Available from: https://ejournal.undip. ac.id/index.php/mkts/article/ view/9254.

25. Relawati R, Baroh I, Ariadi BY. Analisis SWOT untuk Pengembangan Strategi Pemasaran Produk Olahan Apel di Malang Raya [SWOT Analysis for The Development of Apple Product Marketing Strategy in Malang Raya]. 2015. [cited 2020 April 4]. Available from: http://agribisnis. fp.uns.ac.id/analisis-swot.

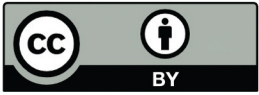

This work is licensed under a Creative Commons Attribution 